\title{
COMPARISON OF THE MODEL CRITICAL DISCOURSE ANALYSIS BY MILLS AND FAIRCLOUGH AT ONLINE MEDIA IN CASE REPORTING OF "IKAN ASIN"
}

\author{
Syarifa Rafiqa \\ Universitas Borneo Tarakan \\ Jl. Amal Lama No. 1. Kota Tarakan, 771112 e-mail: rafiqa@borneo.ac.id
}

\begin{abstract}
This study examines how the relationship between gender language and ideology is constructed in media texts, and aims to interrogate a small number of articles taken from the most widely read online editions of national newspapers in Indonesia regarding online media reporting on the harassment of women in the "Ikan Asin" case. The focuses of this research are 1) how the women are displayed in the text. 2) How media displays texts, discursive practices that include the production and consumption of texts, and social practices. 3) What are the differences between the Mills and Fairlough critical discourse analysis models? The results of the study are that women are displayed positively even though the case they experience is negative. Text production is closely related to the ideology of journalists and the media as well as the audiences who consume the text. Both Mills and Fairclough's critical discourse analysis models have similarities and differences in analyzing texts.
\end{abstract}

Key Words: Critical Discourse Analysis, Mills, Fairclough, Ikan Asin.

Article History: Received: 20/09/2019; Revised: 25/10/2019; Accepted: 28/11/2019; Published: 31/12/2019

How to Cite (MLA $7^{\text {th }}$ ): Syarifa Rafiqa. "Comparison of the model critical discourse analysis by mills dan fairclough at online media in case reoorting of "Ikan asin"." Hortatori Jurnal Pendidikan Bahasa dan Sastra Indonesia vol.3 no.2 (2019): 73-80. Print/Online. Copyrights Holder: Syarifa Rafiqa. First Publication: Hortatori Jurnal Pendidikan Bahasa dan Sastra Indonesia (2019).

This work is licensed under a Creative Commons Attribution-ShareAlike 4.0 International License.

\section{Pendahuluan}

Analisis wacana kritis (AWK) adalah sebuah upaya atau proses (penguraian) untuk memberi penjelasan dari sebuah teks (realitas sosial) yang mau atau sedang dikaji oleh seseorang atau kelompok dominan yang kecenderungannya mempunyai tujuan tertentu untuk memperoleh apa yang diinginkan. Artinya, dalam sebuah konteks harus disadari akan adanya kepentingan. Oleh karena itu, analisis yang terbentuk nantinya disadari telah dipengaruhi oleh si penulis dari berbagai faktor. Selain itu harus disadari pula bahwa di balik wacana itu terdapat makna dan citra yang diinginkan serta kepentingan yang sedang diperjuangkan (Mustofa). Terdapat beberapa tokoh yang memiliki sudut pandang yang berbeda dan cara analisis yang berbeda satu dengan yang lainnya namun sama dalam beberapa pandangan seperti, wacana dapat dimanipulasi oleh kelompok yang berkuasa dalam masyarakat. Perbedaan cara analisis tersebut juga dapat dilihat dari tingkat analisis yang digunakan tokoh tersebut. Dalam hal ini perbedaan terjadi pada tingkat analisis yang digunakan Mills dan Fairlough misalnya. Mills, mempertanyakan bagaimana subjek membentuk dan memposisikan subjek pada posisi tertentu, bagaimana pembaca ditempatkan dalam relasi sosial tertentu yang seringkali timpang dalam hubungan sosial. Sedangkan Fairclough tidak 
hanya memasukan konteks sebagai variabel penting dalam analisis tetapi juga analisis pada tingkat meso yaitu bagaimana konteks itu diproduksi dan dikonsumsi.

Mills menitik beratkan perhatiannya pada wacana mengenai feminisme yang ditampilkan pada media, menunjukkan cara kerja media bias dalam menampilkan wanita (Mills, Language and Sexism). Sedangkan Fairclough berusaha untuk membangun suatu model analisis wacana yang mempunyai kontribusi dalam analisis sosial dan budaya, sehingga ia mengkombinasikan tradisi analisis tekstual yang selalu melihat bahasa dalam ruang tertutup dengan konteks masyarakat yang lebih luas (Fairclough, Critical Discourse Analysis The Critical Study of Langauge). Hal ini senada dengan penelitian yang dilakuakan oleh (Assidik) yang menjelaskan bahwa tidak ada media masa yang sepenuhnya netral sehingga peneliti tergelitik untuk melihat bagaimana media massa mengiring opini publik tentang citra perempuan mengenai kasus "Ikan Asin" tidak dapat dipisahkan dari peran wartawan sebagai composer berita dan media massa tempat ia bernaung. Adapun media massa yang cukup popular saat ini adalah media daring (online) (Annas and Fitriawan). (Romli) yang termasuk kategori media online salah satunya portal berita. Mempelajari perempuan dalam teks pada media online berarti mempelajari cara-cara makna berfungsi untuk mempertahankan dominasi, dengan kata lain bahasa bukan satu-satunya instrumen komunikasi atau bahkan pengetahuan, tetapi juga merupakan instrumen kekuasaan (Fairclough, Critical Discourse Analysis The Critical Study of Langauge; Fairclough, Language and Power; Gowhary et al.; Abadi et al.). Banyaknya berita-berita yang menampilkan perempuan sebagai objek pemberitaan (Sobari and Faridah; Sukaesih and Brida; Setiawan), bahkan hingga saat ini, budaya sampai batas tertentu masih diatur oleh sistem patriarki, status perempuan di masyarakat akan selalu berada di posisi kedua (Radzi and Musa; Zulkifli) akibat dominasi laki-laki ini ideologi dan wacana kewanitaan dan maskulinitas sangat mempengaruhi efek gender dalam lingkungan sosial (Litosseliti and Leadbeater).

Penelitian ini mengkaji secara khusus bagaimana hubungan antara bahasa dan gender dikonstruksi dalam teks-teks media, dan ini bertujuan untuk menginterogasi sejumlah kecil artikel yang diambil dari edisi online surat kabar nasional di Indonesia yang paling banyak dibaca mengenai pemberitaan media online tentang pelecehan perempuan kasus "Ikan Asin". Media dilihat sebagai situs utama untuk membangun diskursif identitas gender dan pemeliharaan ideologi gender dominan (Litosseliti and Leadbeater; McPhillips and Speer; Albaburrahim). Sedangkan Fairclough memahami bahwa wacana tidak dapat dilepaskan dari konteksnya, untuk menemukan realitas dibalik teks diperlukan penelusuran atas konteks produksi teks, konsumsi teks dan aspek sosial budaya yang mempengaruhi pembuatan teks. Sehingga fokus penelitian ini adalah analisis wacana kritis Mills dan Fairclough pada media online dalam pemberitaan seorang mantan suami yang mengatakan mantan istrinya bau "Ikan Asin". Bagaimana perempuan dalam hal ini Fairuz ditampilkan dalam teks. Bagaimana media menampilkan teks, praktik diskursif yang mencakup produksi dan konsumsi teks, dan praktik sosial. Apakah perbedaan kedua model analisis wacana kritis Mills dan Fairlough.

\section{Analisis Wacana Kritis : Sara Mills}

Sebetulnya, banyak model analisis wacana yang diperkenalkan dan dikembangkan oleh para ahli yang menyajikan model-model analisis wacana yang dikembangkan oleh (Fairclough, Critical Discourse Analysis The Critical Study of Language; Dijk; Kress and Leeuwen; Foucault et al.; Mills, Feminist Stylistics). Analisis wacana kritis (AWK) menyediakan teori dan metode yang bisa digunakan untuk melakukan kajian empiris tentang hubungan-hubungan antara wacana dan perkembangan sosial dan kultural dalam domain-domain sosial yang berbeda (Jorgensen and Phillips; Megawati). (Mills, Language and Sexism) menitik beratkan perhatiannya pada wacana mengenai feminisme ditampilkan pada media, menunjukkan cara kerja media bias dalam menampilkan wanita. Dengan demikian apa yang ditampilkan oleh Mills dikenal dengan persfektif feminis. Mills meyakini bahwa teks maupun gambar secara tidak langsung berkomunikasi dengan khalayak. Oleh karena itu Mills memusatkan perhatian pada gender dan posisi subjek-objek. Secara umum, ada dua hal yang diperhatikan dalam anlisis: pertama, bagaimana aktor dalam teks tersebut diposisikan dalam pemberitaan. Siapa pihak yang diposisikan dalam teks dan apa akibatnya. Kedua, bagaimana subjek-objek diposisikan dalam teks. Teks dimaknai di sini sebagai hasil negoisasi antara subjek dan objek.

Disamping itu, (Mills, Feminist Stylistics) juga menaruh perhatian pada bagaimana pembaca dan penulis ditampilkan dalam teks. 1) Posisi Subjek-Objek. Analisis atas bagaimana posisi-posisi aktor dalam teks (program) ditampilkan secara luas akan menyingkap bagaimana ideologi dan kepercayaan dominan bekerja dalam teks. Posisi sebagai subjek atau objek dalam representasi mengandung muatan 
ideologis tertentu. Pertama, posisi ini akan menunjukkan batas tertentu sudut pandang penceritaan. Artinya sebuah peristiwa atau wacana akan dijelaskan dalam sudut pandang subjek sebagai narator dari suatu peristiwa. Dengan demikian, pemaknaan khalayak akan tergantung kepada narator sebagai juru warta kebenaran. Kedua, sebagai subjek representasi narator bukan hanya memiliki keleluasaan dalam menceritakan peristiwa tetapi juga menafsirkan berbagai tindakan yang membangun peristiwa tersebut, dan kemudian hasil penafsirannya mengenai peristiwa itu digunakan untuk membangun pemaknaan dia yang disampaikan kepada khalayak. Ketiga, proses pendefinisian tersebut bersifat subjektif, maka perspektif dan sudut pandang yang dipakai tersebut akan turut berpengaruh terhadap bagiamana sebuah peristiwa dideifinisikan. Dalam wacana feminis, posisi (subjek-objek) dalam wacana akan turut menempatkan posisi perempuan ketika ditampilkan dalam sebuah wacana. 2) Posisi Pembaca. Model yang diperkenalkan oleh (Mills, Feminist Stylistics)mengasumsikan bahwa teks adalah suatu hasil negosiasi antara penulis (media) dan pembaca. Oleh karena itu, Mills berpandangan dalam suatu teks posisi pembaca sangatlah penting dan harus diperhitungkan dalam teks, dalam penelitian ini yaitu bagaimana pembaca diposisikan dalam teks. Bagaimana media melalui teks yang dibuat menempatkan dan memposisikan pembaca dalam subjek tertentu dalam seluruh jalinan teks. Penempatan posisi pembaca ini umumnya berhubungan dengan bagaimana penyapaan/penyebutan dilakukan dalam program yang menurut Mills dilakukan secara tidak langsung (indirect address) melalui dua cara. Pertama, mediasi yaitu penempatan posisi kebenaran pada pihak/karakter tertentu sehingga pendengar akan mensejajarkan dirinya sendiri dengan karakter yang tersaji dalam teks. Kedua, melalui kode budaya atau nilai budaya yang berupa nilai-nilai yang disetujui bersama, yang dipakai pembaca ketika menafsirkan suatu teks.

\section{Analisis Wacana Kritis : Norman Fairclough}

Model analisis wacana kritis yang dibuat (Fairclough, Critical Discourse Analysis The Critical Study of Language) mengintegrasikan secara bersama-sama analisis wacana yang didasarkan pada linguistik, pemahaman sosial dan politik, dan secara umum diintegrasikan pada perubahan sosial. Membagi analisis wacana dalam 3 dimensi yaitu, Text, Discourse Practice, dan Sociocultural Practice. Pada dimensi Text, Teks dianalisis secara linguistik dengan melihat kosakata, semantic, dan tata kalimat serta memasukan koherensi dan kohesi, bagaimana antarkata atau kalimat digabungkan sehingga membentuk pengertian (Mustofa; Saraswati and Sartini). Elemen yang dianalisis tersebut dipakai untuk melihat tiga masalah yaitu (1) ideasional ideasional (representasi teks) yang merujuk pada referensi tertentu yang ditampilkan dalam teks yang umumnya membawa muatan ideologi, (2) relasi(hubungan antara partisipan)yang merujuk pada bagaimana konstruksi hubungan diantara wartawan dengan pembicara yang disampaikan secara informal, terbuka atau tertutup, (3) identitas yang merujuk pada konstruksi tertentu dari identitas penulis dan pembaca serta bagaimana personal dan identitas ini hendak ditampilkan.

Discourse Practice merupakan dimensi yang berhubungan dengan proses produksi dan konsumsi teks. Sementara itu, Sociocultural Practice adalah dimensi yang berhubungan dengan konteks yang memasukkan banyak hal seperti konteks situasi, dan lebih luas lagi memasukkan konteks dan praktik institusi dan media sendiri dalam hubungannya dengan masyarakat atau budaya dan politik tertentu. Bagi Fairclough untuk memahami wacana tidak dapat dilepaskan dari konteksnya karena sebuah teks tidak lepas dari kepentingan yang bersifat subjektif. Untuk menemukan "realitas" di balik teks tersebut diperlukan penelusuran atas konteks produksi teks, konsumsi teks, dan aspek sosial budaya yang mempengaruhi pembuatan teks (Nasir; Fauzan; Fahmi and Nuruddin). Adapun tujuan umum model tiga dimensi ini adalah memberikan kerangka analitis bagi analisis wacana. Model ini didasarkan pada dan menggunakan prinsip yang berbunyi bahwa teks tidak pernah bisa dipahami dalam dianalisis terpisah, hanya bisa dipahami dalam kaitannya dengan jarring-jaring teks lain dan hubungannya dengan konteks sosial (Fairclough, Critical Discourse Analysis The Critical Study of Langauge; Jorgensen and Phillips; Darma; Annas and Fitriawan; Assidik).

\section{Metode}

Metode penelitian yang digunakan adalah metode kualitatif dengan menggunakan pendekatan Analisis Wacana Kritis Sara Mills dan Niorman Fairclough terhadap 2 situs berita online mengenai kasus "Ikan Asin" pada tanggal 1 Juli 2019. Bagaimana berita online menampilkan perempuan sebagai objek pemberitaan. Fenomena pemberitaan mengenai kasus "Ikan Asin" sejak awal hingga saat ini menjadi 
viral dan menarik perhatian pembaca karena perempuan menjadi korban akibat ucapan seorang mantan suami dan ini dianggap sebagai pelecehan terhadap perempuan-perempuan di Indonesia. Adapun situs berita online yang digunakan dalam penelitian ini yaitu 2 situs berita online terbaik dan teratas di Indonesia menurut IT-Jurnal.com yaitu, Detik.com dan Kompas.com. teknik pengumpulan data yang digunakan adalah dokumentasi yang berupa berita yang diterbitkan 2 situs tersebut khususnya yang memuat kasus "Ikan Asin" pada tanggal 1 Juli 2019.

\section{Hasil dan Diskusi}

Model analisis wacana kritis oleh (Mills, Feminist Stylistics; Mills, Language and Sexism) ini memiliki dua konsep dalam analisisnya. Konsep pertama yang ingin dilihat adalah mengenai posisi actor yang ditampilkan dalam teks. Posisi yang dimaksud yaitu posisi subjek dan objek, siapa yang menjadi pencerita (subjek) dan siapa yang diceritakan (objek). Kemudian posisi pembaca, bagaimana posisi pembaca yang ditampilkan dalam teks, bagaimana pembaca memposisikan dirinya dalam teks yang ditampilkan. Kepada kelompok manakah pembaca mengidentifikasikan dirinya serta bagaiman penulis menyampaikan agenda besar yang ingin disampaikan pada pembaca. Analisis wacana kritis (Fairclough, Critical Discourse Analysis The Critical Study of Language; Fairclough, Critical Discourse Analysis The Critical Study of Langauge) dalam analisisnya, Fairclough menawarkan model tiga dimensi yang mewakili tiga domain yang harus dianalisis, yakni teks (ucapan, tulisan, image visual, atau kombinasi dari ketiganya), praktik diskursif yang mencakup produksi dan konsumsi teks, dan praktik sosial.

Kedua model analisis wacana kritis yanag digunakan untuk menganalisis kasus "Ikan Asin" yang saat ini menjadi perbincangan di masyarakat dikarenakan pelecehan perempuan yang dilakukan seorang mantan suami baru pertama kali terjadi terutama mereka adalah public figure yang dikenal secara luas. Dapat dilihat ada beberapa perbedaan yang terjadi dalam analisis wacana kritis yang dianalisis oleh kedua model Mills dan Fairclough. Adapun perbedaan dan persamaan analisis model Mills dan Fairclough dapat dilihat dalam gambar sebagai berikut:

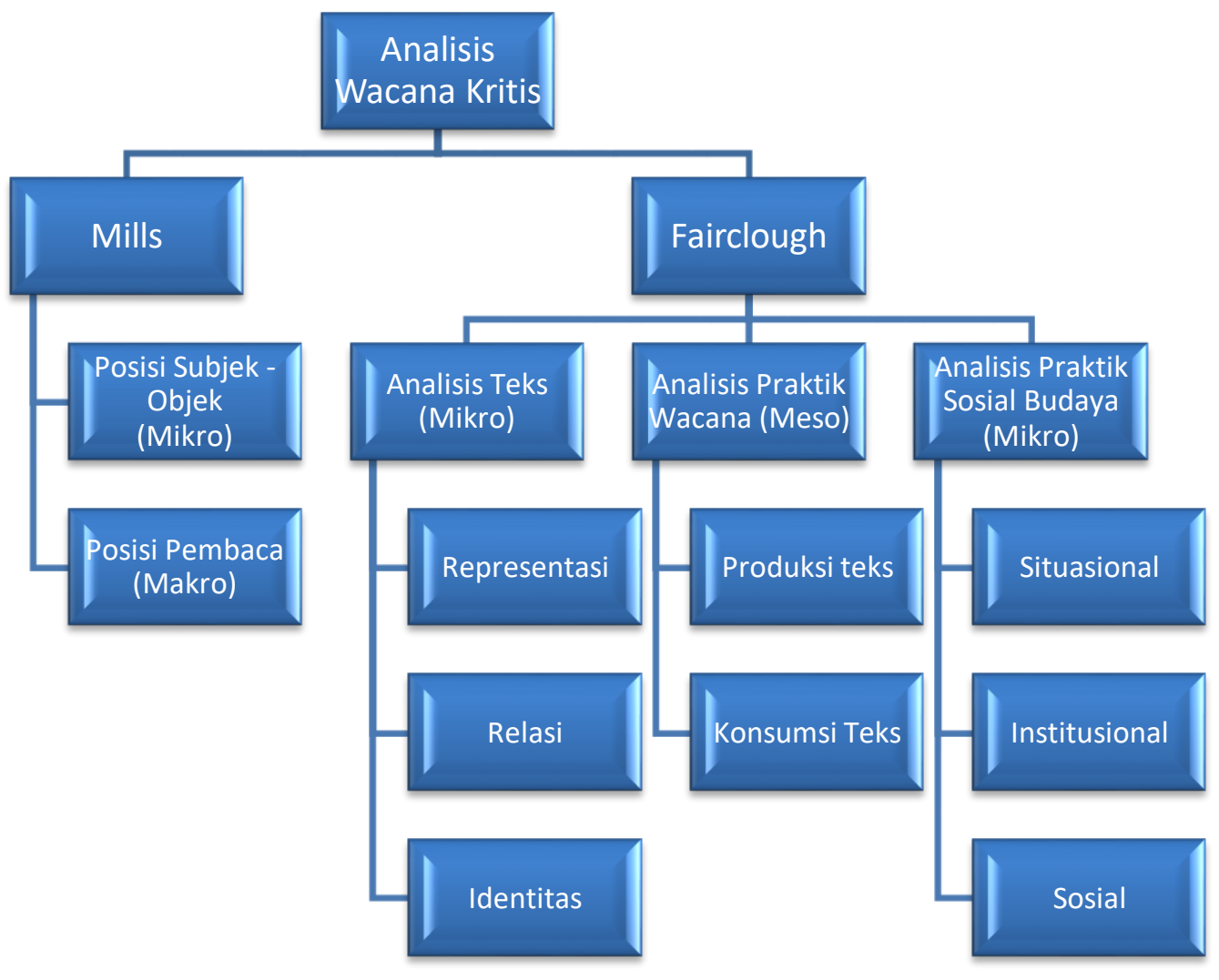

Gambar 1. Perbandingan Analisis Wacana Kritis Mills dan Fairclough 


\section{Analisis Wacana Kritis Mills}

\section{Posisi Subjek-Objek}

Dalam wacana pada situs berita detik.com dengan judul "Disebut Bau Ikan Asin, Fairuz Polisikan Eks Suami dan Youtuber" pada tanggal 1 Juli 2019. Penulis disini sebagai subjek (pencerita) yaitu seorang laki-laki yang bernaama Samsudhuha Wildayansyah dan menampilkan Fairuz sebagai objek yang diceritakan. Fairuz dinilai sebagai wanita muslimah yang baik dalam menjalankan perannya sebagai seorang ibu dan seorang istri yang tidak pernah melakukan hal tercela. Dalam pemberitaan Fairuz memiliki kesempatan untuk menampilkan dirinya sendiri dan ditampilkan oleh penulis dengan mengutip beberapa gagasan yang dikemukakan oleh juru bicara Fairus yaitu kakaknya sebagai berikut:

"Fairuz sebagai wanita muslimah yang selama ini menjadi seorang ibu dan seorang istri yang tidak pernah melakukan perbuatan tercela, namun tiba-tiba suami Fairuz yang sudah bercerai sejak 2015 bekerja sama dengan pemilik akun youtube Rei Utami dan Benua menyebarkan kalimat-kalimat konten asusila di postingan akun youtube tersebut"

Sedangkan kompas.com dengan judul beritanya "Mantan Suami Fairuz Dilaporkan atas Kasus Ucapan Bau Ikan Asin" pada tanggal 1 Juli 2019. Subjeknya seorang perempuan bernama Rindi Nuris Velarosdela yang menulis dalam beritanya bagaimana Fairuz merasa harga dirinya diinjak-injak sebagai seorang perempuan yang diperolok dengan konten asusila. Pemberitaan ini sedikit berbeda ketika subjeknya adalah seorang perempuan. Fairuz digambarkan sebagai perempuan yang sabar, ibu penuh dengan kasih, berani dan tegas. Dalam pemberitaan Fairuz ditampilkan oleh penulis dengan beberapa gagasan seperti, fairuz sempat memprotes unggahan video tersebut namun tak mendapatkan respon dari pihak Galih. Selanjutnya Fairuz juga memiliki kesempatan untuk menampilkan dirinya sendiri yang dikemukakan oleh juru bicara Fairuz yaitu kakaknya sebagai berikut:

"Pemilik akun Youtube Rey Utami dan Benua menyebarkan kalimat konten asusila yang

menyebutkan organ intim bau ikan asin. Kalimat tersebut sangat melukai hati Fairuz

dan seluruh wanita Indonesia"

Dari temuan data diatas dapat kita simpulkan bahwa penulis perempuan dan penulis laki-laki sangat berbeda dalam menuliskan sebuah berita, berita yang tanggal, objek dan topiknya sama namun diulas dengan berbeda. Hal ini dapat dilihat dengan dua media yang berbeda dan 2 penulis yang berbeda jenis kelamin. Bagaimana mereka menuliskan gagasan tentang kasus "Ikan Asin" dalam teks pemberitaan. Penulis laki-laki dari situs detik.com menampilkan sosok Fairuz sebagai korban yang melaporkan mantan suaminya, sedangkan penulis perempuan menuliskan gagasan dengan menampilkan Fairuz sebagai perempuan yang sabar, ibu penuh dengan kasih, berani dan tegas. Hal ini mengindikasikan bahwa perempuan memiliki kesadaran untuk mengembangkan perspektif para jurnalis perempuan mengenai isu perempuan (Suhara).

\section{Posisi Pembaca}

Teks dianggap sebagai negoisasi antara penulis dan pembaca, posisi pembaca juga merupakan hal yang penting untuk dianalisa. Penempatan posisi pembaca ini berhubungan dengan penyapaan /penyebutan kepada pembaca yang ditampilkan dalam pemberitaan. Hal ini dilakukan secara tidak langsung yaitu melalui 'mediasi dan 'kode budaya' (Mills, Feminist Stylistics). Teks pada situs detik.com penulis memasukan unsur kode budaya untuk membantu pembaca menempatkan dirinya terutama dengan orientasi nilai yang disetujui dan dianggap benar. Dengan disisipkannya kode budaya seperti "memperolok dengan konten asusial", "harga dirinya diinjak-injak sebagai perempuan" maka pembaca akan menyetujui gagasan dari penulis terhadap orientasi nilai yang ada pada masyarakat, sehingga pembaca akan menempatkan dirinya pada tokoh utama dalama teks. Sedangkan teks pada situs kompas.com penulis menyisipkan unsur mediasi sebagai alat berneoisasi antara penulis dan pembaca. Kalimat sapaan "ketiga terlapor" tersebut, otomatis akan mengarahkan pembaca untuk menyetujui gagasan yang dikemukakan penulis atas pelaporan Fairuz, sehingga prilaku memperolok dengan konten asusila merupakan kejahatan, maka otomatis akan mengarahkan pembaca untuk memposisikan diri sebagai pelaku perbuatan asusila tersebut dengan memberikan informasi tentang hukuman dan undang-undang yang berlaku, sehingga menjadi tersangka atas pelaporan pencemaran nama baik merupakan salah satu konsekuensinya. 


\section{Analisis Wacana Kritis Fairclough \\ 1. Analisis Teks}

Fairclough membagi analisis wacana menjadi tiga elemen dasar untuk menguraikan dan menganalisis teks yaitu representasi, relasi dan identitas. 1) Representasi, terdapat tiga alat yang digunakan detik.com dalam mempresentasikan pelecehan perempuan dan tokoh yang terlibat, yaitu diksi, penggunaan kalimat luas sebab akibat dan banyak mengutip langsung pernyataan narasumber. Sedangkan Kompas.com cenderung lebih berpihak pada korban, hal ini terlihat dari penggunaan diksi melontarkan, bernada negatif, tidak mendapatkan respon dan melaporkan yang memiliki makna eksplisit untuk menggambarkan kejahatan yang dilakukan pelaku. 2) Relasi berhubungan dengan pertanyaan bagaimana partisipasi masyarakat/kelompok dalam media berhubungan dan ditampilkannya dalam teks. Ditampilkannya narasumber tambahan yaitu Hotman Paris selaku pengacara Fairuz dengan memberikan penjelasan tambahan tentang pelaporan Fairuz sudah atas perintah keluarga besar Fairuz. Sedangkan kompas.com tidak ada kelompok atau golongan lain yang menyampaikan gagasan mereka. Hanya kakak dari Fairuz selaku juru bicara yang menyampaikan pandangannya. 3) Identitas, detik.com mencoba menggambarkan kondisi dan peristiwa yang cenderung lebih pro kepada korban. Peristiwa ini melibatkan keluarga korban dan pengacara korban sebagai narasumber. Penulis berita tidak menampilkan pelaku dalam teks untuk memberikan klarifikasi atas tindakan pelecehan perempuan yang mereka lakukan. Sedangkan kompas.com menggambarkan peristiwa "Ikan Asin" cenderung mendukung korban dengan beberapa kutipan tak langsung yang dituliskan penulis. Dari keseluruhan berita tentang kasus "Ikan Asin" yang dianalisis, memperlihatkan bahwa penulis menggambarkan kasus ini adalah kasus berat tentang pelecehan Fairuz sebagai perempuan.

\section{Analisis Praktik Wacana}

Analisis praktik kewacanaan dipusatkan pada bagaimana teks diproduksi dan dikonsumsi (Fairclough, Critical Discourse Analysis The Critical Study of Language; Jorgensen and Phillips). Dalam pandangan fairclough, ada dua sisi dari praktik diskursus tersebut, yakni produksi teks (dipihak media) dan konsumsi teks (di pihak khalayak). Proses produksi teks detik.com dimulai dengan peliputan, penulisan naskah, penyuntingan naskah (editing) dan produksi serta di upload. Karena detik.com memberikan informasi secara cepat.penulisan naskah teks dilakukan oleh seorang laki-laki sehingga didalam teks lebih banyak kutipan langsung. Sedangkan proses produksi teks kompas.com dimulai dengan peliputan, penulisan naskah, penyuntingan naskah (editing) dan produksi serta di upload. Karena kompas.com memberikan informasi secara cepat. Penulisan naskah yang dilakukan oleh penulis perempuan lebih cenderung mendukung korban dengan adanya gagasan-gagasan dari penulis. Pada umumnya semua media mempunyai 'pasar' nya masing-masing. Media memiliki tanggung jawab atas konten berita yang disampaikan kepada pembaca agar terhindar dari berita hoax. Sehingga berita layak untuk dikonsumi oleh khalayak.

\section{Analisis Praktik Sosial Budaya}

Fairclough membagi tiga level analisis pada praktik sosial budaya yaitu, Situasional, Institusional dan sosial. 1) Situasional. Media mengangkat fenomena yang mempunyai nilai berita, tentu saja berita yang dianggap penting dan layak untuk disajikan. Peristiwa ini juga mendapat banyak perhatian dari media. Kasus "Ikan Asin" kasus yang berbeda dari kasus artis-artis lainnya. Sehingga kasus "Ikan Asin" ini layak disajikan hampir di semua media, baik cetak maupun elektronik mengangkat berita ini, karena layak untuk disajikan di khalayak. 2) Institusional. Penulisan teks pemberitaan detik.com dalam kasus "Ikan Asin" melibatkan pihak firma hukum Hotman Paris \& Partners. Dengan hadirnya narasumber dalam teks, media memberitahukan bahwa siapa saja yang melakukan pencemaran nama baik di sosial media dapat terjerat UU ITE. Sedangkan dalam penulisan teks berita kompas.com tidak melibatkan pihak manapun. Namun sangat disayangkan bahwa dalam teks tidak menampilkan pihak Kepolisian, firma hukum dan Lembaga Sensor Film. 3) Sosial. Pengaruh sosial dan kultural memainkan peranan dalam menentukan konten-konten yang layak dan tidak diangkat dalam vlog. Banyaknya youtuber yang mengejar konten popular sehingga melupakan norma-norma dalam masyarakat. Sehingga mereka menghalalkan segala cara demi menaikan jumlah subscriber. Munculnya teks pemberitaan tentang kasus "Ikan Asin" awalnya dipicu oleh komentar-komentar masyarakat akibat adanya video vlog Rey Utami. Banyak perempuan/ibu-ibu yang merasa sangat dilecehkan dengan ungkapan Galih yang melontarkan pernyataan bernada negatif terkait organ intim mantan istrinya, selanjutnya banyak orang 
yang prihatin kepada Fairuz. Salah satunya adalah muncul dari seorang pengacara yaitu Hotman Paris yang menyarankan Fairuz menempuh jalur hukum, dan siap untuk menjadi pengacaranya.

\section{Simpulan}

Persamaan model analisis wacana kritis khususnya Mills dan Fairclough sebagai berikut; 1) ideologi menjadi bagian utama bahkan terpenting dalam analisis wacana kritis. 2) kedua model AWK Mills dan Fairclough berpandangan bahwa wacana dapat dimanipulasi oleh kelompok yang dominan atau kelompok yang berkuasa dalam masyarakat. 3) analisis menggunakan unit bahasa untuk mendeteksi ideologi yang tersembunyi didalam teks. Sedangkan perbedaan dari keduanya yaitu, 1) terutama terletak pada hubungan antara teks dengan konteks sosial masyarakat. 2) terletak pada tingkatan analisis. Ada tiga tingkatan dalam analisis wacana kritis yaitu mikro, meso dan makro. Mills menggunakan analisis mikro dan makro sedangkan Fairclough menggunakan analisis mikro, meso dan makro. Jika kita kaji lebih dalam analisis makro dan mikro yang dilakukan Mills dan Fairclough juga berbeda, karena Fairclough analisisnya lebih detail dan spesifik daripada Mills.

Perbandingan analisis wacana kritis model Mills dan Fairclough dalam pemberitaan kasus "Ikan Asin". Mills melihat bagaimana objek (Fairuz) diceritakan dalam teks dengan subjek yang berbeda, ketika laki-laki yang menjadi subjek maka pembaca akan menyetujui gagasan dari penulis terhadap tokoh utama sedangkan ketika perempuan yang menjadi subjek maka penempatan posisi pembaca dalam berita ini menjadi salah satu faktor yang membantu terbentuknya konstruksi perempuan yang memiliki citra positif. Sedangkan Fairclough selain melihat unsur kebahasaan yang digunakan dalam teks, juga relasi yang ada didalam teks seperti narasumber tambahan serta penempatan penulis dalam berita apakah pro atau kontra pada kasus "Ikan Asin" kedua wartawan pro kepada korban dengan perbedaan diksi yang sangat terlihat. Selanjutnya bagaimana proses produksi yang dilakukan media dan siapa saja yang mengkonsumsi berita tersebut. Produksi teks berhubungan erat dengan ideologi wartawan dan media yang menanunginya sehinga ini menjadi menarik untuk dibahas lebih lanjut. Perlu diketahui bahwa kenapa sebuah berita penting untuk disajikan dalam hal ini kasus "Ikan Asin" merupakan kasus yang dianggap berbeda dari kasus artis lainnya. Pihak-pihak yang terlibat secara institusi yaitu kepolisian, firma hukum dan lembaga sensor film. Terakhir, Pengaruh sosial dan kultural memainkan peranan dalam menentukan konten-konten yang layak dan tidak diangkat dalam vlog. Banyaknya youtuber yang mengejar konten popular sehingga melupakan norma-norma dalam masyarakat. Sehingga mereka menghalalkan segala cara demi menaikan jumlah subscriber.

\section{Daftar Rujukan /}

Abadi, Imron, et al. "Bentuk Hegemoni Kekuasaan Dalam Tuturan 'Jokowi.'” JPH - Jurnal Pendidikan Humaniora, vol. 4, no. 4, 2016, pp. 209-17, doi:10.17977/jph.v4i4.8204.

Albaburrahim. "Analisis Wacana Kritis Pada Pemberitaan Kasus Papa." Lingua Franca: Jurnal Bahasa Dan Sasatra Pengajarannya, vol. 5, no. 2, 2017, pp. 1-12.

Annas, Akhirul, and Rana Akbari Fitriawan. "Media Dan Kekerasan : Analisis Norman Fairclough Terhadap Pemberitaan Tarung Gladiator." Jurnal Sospol, vol. 4, no. 1, 2018, pp. 37-54.

Assidik, Gallant Karunia dan Wahyudi Joko Santoso. "Citra Publik Presiden Republik Indonesia Pada Pemberitaan Di Harian Suara Merdeka, Tabloid Tempo, Dan Harian Republika: Kajian Analisis Wacana Kritis Model Norman Fairclough." Seloka: Jurnal Pendidikan Bahasa Dan Sastra Indonesia, vol. 5, no. 2, 2016, pp. 201-15.

Darma, Yoce Aliah. "Metode Pembelajaran Penerjemahan." Jurnal Pendidikan Dan Kebudayaan, vol. 13, no. 67, 2007, p. 678, doi:10.24832/jpnk.v13i67.391.

Dijk, Van Teun. Discourse as Structure and Process (Discourse Studies A Multidisciplinary Introductio). SAGE Publication Ltd, 1997.

Fahmi, A. K., and Nuruddin. "Nilai Pendidikan Akhlak Dalam Syair Imam Al-Syafi.i (Kajian Struktural Genetik)." Jurnal Arabiyat, vol. 1, no. 2, 2014, pp. 181-94.

Fairclough, Norman. Critical Discourse Analysis The Critical Study of Langauge. Second Edi, Routledge, 2010.

---. Critical Discourse Analysis The Critical Study of Language. Longman Publishing, 1995.

---. Language and Power. Longman Publishing, 1989. 
Fauzan, Umar. “Analisis Wacana Kritis Dari Model Fairclough Hingga Mills.” Jurnal Pendidik, vol. 19, no. 1, 2014, pp. 27-40, doi:10.1177/1742766510373715.

Foucault, Michel, et al. Discourse The New Critical Idiom. Routledge, 1997.

Gowhary, Habib, et al. "A Critical Discourse Analysis of the Electoral Talks of Iranian Presidential Candidates in 2013." Procedia - Social and Behavioral Sciences, vol. 192, Elsevier B.V., 2015, pp. 132-41, doi:10.1016/j.sbspro.2015.06.020.

Jorgensen, Marianne, and Louise J. Phillips. Discourse Analysis as Theory and Method. SAGE Publication Ltd, 2002.

Kress, Gunther, and Van Theo Leeuwen. Multimodal Discourse The Modes and Media of Contemporary Communication. Edited by Oxford University Press, 2001.

Litosseliti, Lia, and Claire Leadbeater. "Speech and Language Therapy/Pathology: Perspectives on a Gendered Profession." International Journal of Language and Communication Disorders, vol. 48, no. 1, 2013, pp. 90-101, doi:10.1111/j.1460-6984.2012.00188.x.

McPhillips, Rebecca, and Susan A. Speer. "Sexist Discourse." The International Encyclopedia of Language and Social Interaction, 2015, pp. 1-6, doi:10.1002/9781118611463.wbielsi111.

Megawati, Erna. "Ekspresi Emosi Dan Gender Pada Komentar Vlog Dzawin Nur Episode Coki Pardede : Komika Tak Beragama." Jurnal Wacana, vol. 3, no. April, 2019, pp. 17-27.

Mills, Sara. Feminist Stylistics. Routledge, 1995.

---. Language and Sexism. Cambridge University Press, 2008.

Mustofa. "Analisis Wacana Kritis ( Awk ) Dalam Cerpen Dua Sahabat Karya Budi Darma : Konteks Pembelajaran Bahasa Dan Sastra Indonesia." BASTRA, vol. 1, no. 1, 2014, pp. 13-22.

Nasir, Sanat. "Ucapan Bajet 2006 Oleh Perdana Menteri Malaysia: Analisis Wacana Kritis Plus Dalam Perbandingan." Jurnal Pengajian Melayu, vol. 16, no. 11, 2005, pp. 218-40.

Radzi, Nur Syuhada Mohd, and Mahfuza Musa. "Beauty Ideals, Myths and Sexisms: A Feminist Stylistic Analysis of Female Representations in Cosmetic Names." GEMA Online Journal of Language Studies, vol. 17, no. 1, 2017, pp. 21-38, doi:10.17576/gema-2017-1701-02.

Romli, Asep Syamsul. Jurnalistik Online. Panduan Praktis Mengelola Media Online. Nuansa Cendekia, 2012.

Saraswati, Ardhina, and Ni Wayan Sartini. Wacana Perlawanan Persebaya 1927 Terhadap PSSI: Analisis Wacana Kritis Norman Fairclough ( Persebaya 1927 's Resistance Against PSSI : A Norman Fairclough 's Critical Discourse Analysis Study ). Vol. 17, no. november 2016, 2017, pp. 181-91.

Setiawan, Yuliyanto Budi. "Analisis Wacana Kritis Pemberitaan Kekerasan Berbasis Gender Di Surat Kabar Harian Suara Merdeka." Jurnal IImiah Komunikasi: MAKNA, vol. 2, no. 1, 2011, pp. 1320.

Sobari, Teti, and Lilis Faridah. "Model Sara Mills Dalam Analisis Wacana Peran Dan Relasi Gender." Jurnal IImiah Program STudi Pendidikan Bahasa Dan Sastra Indonesia, 2012, pp. 88-99.

Suhara, Rizki Budhi. "Jurnalis Perempuan Dalam Media Massa (Kajian Teori Strukturasi)." Jurnal Unsgawati, vol. 6, no. 2, 2016, p. 103.

Sukaesih, Ina, and Lenny Brida. "Assessing Text Alignment: Sara Mills ' Model." Journal Epigram, vol. 14, no. 1, 2017, pp. 83-88.

Zulkifli, Che Nooryohana. "The Construction of Career Women in Cleo: Critical Discourse Analysis." Procedia - Social and Behavioral Sciences, vol. 208, no. Icllic 2014, Elsevier B.V., 2015, doi:10.1016/j.sbspro.2015.11.179. 